\title{
Dermatology
}

\section{Polymorphisms in Genes Involved in Steroidogenesis in the Development of Severe Acne}

\author{
Alexander G. Rumyantsev ${ }^{1,2}, \mathrm{PhD}, \mathrm{ScD}$; Olga M. Demina ${ }^{2,1^{*}}, \mathrm{PhD}$ \\ ${ }^{I}$ Dmitry Rogachev National Research Center of Pediatric Hematology, Oncology and Immunology \\ ${ }^{2}$ Pirogov Russian National Research Medical University \\ Moscow, the Russian Federation
}

\begin{abstract}
Background: Acne is a multifactorial disease, in the pathogenesis of which one of the leading factors is the excessive effect of androgens on the hair follicles and sebaceous glands, along with hypersecretion of sebum, pathological follicular hyperkeratosis and an inflammatory response. The search for genotypic markers in patients with varying severity of acne is a difficult task due to the multifactorial pathogenesis and the role of trigger factors in the formation of acne. The aim of this study was to determine SNPs within 3 genes involved in steroidogenesis (MVK, ARPC1B, and CA2) in patients with severe acne.

Methods and Results: The study included 70 patients (42 men and 28 women) aged between 15 and 46 years (the median age - 22.1 years). The main group included 50 patients ( 29 men and 21 women) with severe acne. The control group consisted of 20 apparently healthy individuals (13 men and 7 women). Molecular-genetic diagnostics was carried out by the method of highthroughput DNA sequencing (next-generation sequencing). Our study showed that severe acne is associated with 12 polymorphic loci of the $M V K$ gene (4 SNPs in exons and 8 SNPs in introns), 7 SNPs of the $A R P C 1 B$ gene (2 SNPs in exons and 5 SNPs in introns), and 9 SNPs of the $C A 2$ gene (3 SNPs in exons and 6 SNPs in introns).

Conclusion: The revealed features of the SNPs within the $M V K, A R P C 1 B$, and CA2 genes in patients with severe acne probably indicate a hereditary determination of steroidogenesis in acne. The imbalance in the work of the regulatory genes of androgens and estrogens apparently causes an imbalance in the androgen/estrogen ratio in the blood serum towards an increase in androgens against the background of a decrease in estrogens, while their values remain in the normal range. (International Journal of Biomedicine. 2021;11(3):275-280.)
\end{abstract}

Key Words: acne $\bullet$ hair follicle $\bullet$ sebaceous gland $\bullet$ steroidogenesis $\bullet$ single nucleotide polymorphism

For citation:Rumyantsev AG, Demina OM. Polymorphisms in Genes Involved in Steroidogenesis in the Development of Severe Acne. International Journal of Biomedicine. 2021;11(3):275-280. doi:10.21103/Article11(3)_OA4

\section{Abbreviations}

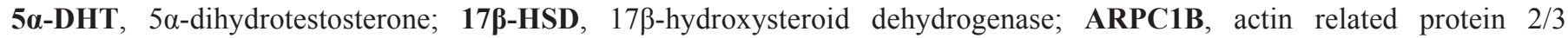
complex subunit 1B; CA2, carbonic anhydrase 2; DHEAS, dehydroepiandrosterone sulfate; DHT, dihydrotestosterone; LPS, lipopolysaccharide; MVK, mevalonate kinase; SNP, single nucleotide polymorphism.

\section{Introduction}

Acne is a multifactorial disease, in the pathogenesis of which one of the leading factors is the excessive effect of androgens on the hair follicles and sebaceous glands, along with hypersecretion of sebum, pathological follicular

*Corresponding author: Olga M. Demina, PhD. Pirogov Russian National Research Medical University. Moscow, Russia. E-mail:demina.75@mail.ru hyperkeratosis and an inflammatory response. The role of androgens in the pathophysiology of acne has been confirmed by numerous experimental and clinical observations. It is known that the development of prepubertal acne is due to the influence of freely circulating dehydroepiandrosterone sulfate (DHEAS). A positive correlation has been noted for the formation of acne in children with congenital adrenal hyperplasia or virilizing tumors. ${ }^{(1,2)}$

There is evidence that hair follicles are influenced by both systemically synthesized androgens and locally secreted 
androgen metabolites, such as testosterone and $5 \alpha-$ DHT. At the same time, in the vast majority of acne patients, serum androgen levels remain within normal values. ${ }^{(3)}$ It has been shown that the absence or rarity of acne in men who underwent premature castration before puberty, or in people with androgen insensitivity syndrome, indicates the role of androgens in the etiology of acne. ${ }^{(4)}$

There is a positive correlation between systemic/local treatment with androgens or anabolic steroids, and serum androgen levels and acne in women. However, women without hyperandrogenism may develop cystic nodular acne and androgenic alopecia. This may be due to the presence of androgen receptors; testosterone and DHT act through a single nuclear receptor, the androgen receptor. ${ }^{(5,6)}$

The synthesis and composition of sebum is regulated by internal (e.g., PPAR, LXR, RAR, RXR, endocannabinoids) and external (e.g., androgens, Insulin-like growth factor 1, insulin, leptin) factors. ${ }^{(7)}$

As known, SF is not only a producer of sebum, but also plays a key role in the local immune system of the skin. Thus, sebocytes under the influence of bacterial flora, in particular Cutibacterium acne (C. acnes), and endogenous mediators, produce a wide range of pro-inflammatory cytokines and growth factors. C. acnes induces the secretion of TNF $\alpha$ and IL-8/CXCL-8, and bacterial LPS further increases the level of IL-1 $\alpha{ }^{(8,9)}$ There is evidence that arachidonic acid is an endogenous mediator of inflammation, which in synergy with elevated intracellular calcium levels induces excessive secretion of IL-6 and IL8. ${ }^{(10)}$

The regulating effect of androgens on sebaceous glands has been established. This effect is realized through androgen receptors expressed on the sebaceous glands. Androgens stimulate the proliferation of the sebaceous glands, and the activation of lipid synthesis in thesebaceous glands occurs in the presence of coactivators, for example, linoleic acid. ${ }^{(11)} \mathrm{At}$ the same time, it has been found that androgens have a more pronounced activating effect on the sebaceous gland sebocytes of the facial skin than those in other areas of the skin. ${ }^{(12)}$

Recent studies have shown that, in addition to interacting with androgens via receptors, sebaceous glands have a number of other important functions. First, the P450 side chain cleavage factors expressed by sebocytes convert cholesterol into pregnenolone. Second, sebaceous glands are

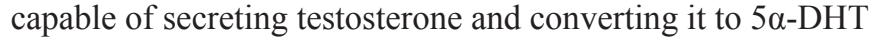
against the background of simultaneous PPAR stimulation. ${ }^{(13)}$ Third, in differentiated sebocytes (in situ) there is an inverse correlation between the expression of 17 $\beta$-HSD and PPAR $\gamma$. And fourth, sebocytes have an inactivating function in relation to testosterone through its conversion to androstenedione, and then to $5 \alpha$-androstenedione. ${ }^{(7)}$

In contrast to the prolipogenic effect of androgens, estrogens have the opposite effect, namely, they reduce the proliferation of sebocytes and inhibit the production of sebum. ${ }^{(14)}$ Acne patients also have lower levels of serum estradiol and sex hormone binding globulin, and combined oral contraceptives have been effective in acne patients, supporting the idea that estrogens reduce the function of sebaceous glands. ${ }^{(15,16)}$ However, later studies provide conflicting data, in particular, despite the fact that the expression of $\alpha$ - and $\beta$-estrogen receptors in the sebaceous glands has been described, 17 $\beta$-estradiol and progesterone did not have a noticeable effect on either proliferation or lipid production by SZ95 sebocytes. ${ }^{(17)}$

The search for genotypic markers in patients with varying severity of acne is a difficult task due to the multifactorial pathogenesis and the role of trigger factors in the formation of acne. ${ }^{(18,19)}$ In patients with severe acne, 2 significant SNPs were identified at the $11 \mathrm{p} 11.2$ locus $(D D B 2$, rs747650 and rs1060573) and one SNP at the 1q24.2 locus (SELL, rs7531806), which regulate androgen metabolism, inflammation and scar formation. ${ }^{(20)}$ There is a hypothesis that nodular cystic acne in women without signs of hirsutism is associated with polymorphism of the CAG-repeats of the androgen receptor gene $(A R G){ }^{(21)}$

The aim of this study was to determine SNPs within 3 genes involved in steroidogenesis ( $M V K, A R P C 1 B$, and $C A 2)$ in patients with severe acne.

\section{Materials and Methods}

The study included 70 patients ( 42 men and 28 women) aged between 15 and 46 years (the median age - 22.1 years). The main group (MG) included 50 patients ( 29 men and 21 women) aged between 15 and 46 years (the median age - 23.2 years) with severe acne. The control group (CG) consisted of 20 apparently healthy individuals ( 13 men and 7 women) aged between 16 and 40 years (the median age -19.4 years). MG and CG were comparable in age and sex characteristics.

All patients of MG suffered from a severe form of acne, which was clinically characterized by multiple open and closed comedones, inflammatory deep papules, pustules, nodules merging into conglomerates, atrophic scars, postinflammatory congestive cyanotic spots with predominant localization on the skin of the face, back, and chest. The skin in the lesions had a greasy appearance; subjective sensations were characterized by mild to moderate pain, aggravated by movement and palpation.

Molecular-genetic diagnostics was carried out by the method of high-throughput DNA sequencing (next-generation sequencing) in the Department of Molecular Genetics at the NMRC PHOI, named after Dmitry Rogachev (Moscow, Russia). Genomic DNA was isolated from whole blood samples of examined patients using the CellSep Advanced Kit (DiaSorin Ireland Ltd., Ireland) according to the manufacturer's instructions.

To assess the population frequencies of the identified variants, we used the data of the international project gnomAD Exomes (ExAC) for exon variants and the gnomAD Genomes database for intron variants. For computer assessment of the pathogenicity of the missense variants we found, the programs for predicting the pathogenicity of amino acid substitutions (SIFT, PolyPhen-2, PROVEAN, UMD Predictor) were used. The MutationTaster, Human Splicing Finder, and NNSplice programs were used for computer prediction of the effect of changes in the splicing sites or areas adjacent to the splicing site. 
This study was approved by the Ethics Committee of the PRNRMU of the Ministry of Healthcare of the Russian Federation and complies with Ethical Principles for Medical Research Involving Human Subjects, Adopted by the 18th WMA General Assembly, Helsinki, Finland, June 1964, and amended by the 59th WMA General Assembly, Seoul, Republic of Korea, October 2008. All patients gave their written informed consent.

Statistical analysis was performed using statistical software package XLSTAT 2019. Odds ratios (ORs) and their 95\% confidence intervals (CIs) were calculated to determine associations between the polymorphisms and essential hypertension. Two-tailed $P$ values $<0.05$ were considered statistically significant.

\section{Results}

In the main group, we identified 21 SNPs within the MVK gene (chromosome 12), 12 SNPs within the ARPC1B gene (chromosome 7), and 11 SNPs within the $C A 2$ gene (chromosome 8).

The detailed analysis for the $M V K$ gene showed that 5 SNPs were localized in exons (4 synonymous and 1 nonsynonymous), 15 SNPs were localized in introns, and one SNP - in the 5'UTR zone. Analysis of the ARPC1B SNPs showed that 3 SNPs were localized in exons, 8 SNPs in introns, and one SNP in the 3'UTR zone. Analysis of the CA2 SNPs showed that 3 SNPs were localized in exons and 8 SNPs in introns. Characteristics of SNPs of the study genes in exons and introns in acne patients are presented in Tables 1-6.

As shown in Table 1, the $M V K$ rs7957619 SNP is localized in exon 3, 2 SNPs in exon 5 (rs34368092 and rs2287218), and 2 SNPs (rs72648042, rs748947620) in exon 9. The OR results showed that 4 out of 5 polymorphic loci of the $M V K$ gene in exons [rs7957619 $(\mathrm{OR}=1.33), \mathrm{rs} 34368092$ $(\mathrm{OR}=3.01), \mathrm{rs} 2287218(\mathrm{OR}=3.08), \mathrm{rs} 748947620(\mathrm{OR}=1.22)]$ are associated with the development of severe acne $(P<0.05)$, and SNP rs72648042 appears to have a protective effect in the development of acne $(\mathrm{OR}=0.08)$.

Table 1.

Characteristics of SNPs within exons of the MVK gene in acne patients

\begin{tabular}{|c|c|c|c|c|c|}
\hline SNPid & $\begin{array}{c}\text { Position } \\
\text { Chr (12) }\end{array}$ & Substitution & $\begin{array}{c}\text { Exone } \\
\text { number }\end{array}$ & $\begin{array}{c}\text { Type and } \\
\text { position of } \\
\text { substitution }\end{array}$ & OR \\
\hline rs7957619 & 110013879 & nonsynonymous & 3 & c.G155A & 1.33 \\
\hline rs34368092 & 110019233 & synonymous & 5 & c.G405A & 3.01 \\
\hline rs2287218 & 110019338 & synonymous & 5 & c.C510T & 3.08 \\
\hline rs72648042 & 110032871 & synonymous & 9 & c.C768T & 0.08 \\
\hline rs748947620 & 110032922 & synonymous & 9 & c.C819T & 1.22 \\
\hline
\end{tabular}

We identified one polymorphic locus the $M V K$ gene for the first time, and it was not previously described in any disease
(Table 2). The OR results showed that 8 SNPs of the $M V K$ gene in introns [rs3759387 $(\mathrm{OR}=1.30), \mathrm{rs} 66616264(\mathrm{OR}=1.30)$, rs6606734 (OR=1.87), rs3752662 $(\mathrm{OR}=1.30), \quad \mathrm{rs} 11615637$ $(\mathrm{OR}=3.08), \mathrm{rs} 2270375 \quad(\mathrm{OR}=1.89), \mathrm{rs} 35191208 \quad(\mathrm{OR}=3.08)$, rs2270374 $(\mathrm{OR}=3.08)]$ are associated with the development of severe acne $(P<0.05)$, whereas 7 SNPs in introns [rs61940512 $(\mathrm{OR}=0.89), \mathrm{rs} 104895343(\mathrm{OR}=0.40), \mathrm{rs} 67886029(\mathrm{OR}=0.62)$, rs7311653 (OR=0.89), -(.) $(\mathrm{OR}=0.94)$, rs72648031 ( $\mathrm{OR}=0.62)$, rs72648041 (OR=0.08)] and SNP rs67606936 in 3'UTR $[\mathrm{rs67606936}(\mathrm{OR}=0.05)]$ are likely to have a protective effect $(P<0.05)$ in the development of severe acne (Table 2$)$.

Table 2.

Characteristics of SNPS within introns and 5'UTR of the MVK gene in acne patients

\begin{tabular}{|c|c|c|c|c|}
\hline SNPid & $\begin{array}{l}\text { Position } \\
\text { Chr (12) }\end{array}$ & $\begin{array}{l}\text { Intron } / \\
\text { 5'UTR }\end{array}$ & Type of substitution & OR \\
\hline rs3759387 & 110012467 & intron & $\mathrm{G}>\mathrm{T}$ & 1.30 \\
\hline rs66616264 & 110012510 & intron & $\mathrm{C}>\mathrm{G}$ & 1.30 \\
\hline rs61940512 & 110012766 & intron & $\mathrm{A}>\mathrm{G}$ & 0.89 \\
\hline rs 104895343 & 110012882 & intron & $\mathrm{G}>\mathrm{A}$ & 0.40 \\
\hline rs6606734 & 110013639 & intron & $\mathrm{T}<\mathrm{G}$ & 1.87 \\
\hline rs3752662 & 110014055 & intron & $\mathrm{C}>\mathrm{T}$ & 1.30 \\
\hline rs67886029 & 110017759 & intron & $\mathrm{C}>\mathrm{T}$ & 0.62 \\
\hline rs7311653 & 110023672 & intron & $\mathrm{G}>\mathrm{A}$ & 0.89 \\
\hline rs 11615637 & 110023689 & intron & $\mathrm{G}>\mathrm{A}$ & 3.08 \\
\hline rs 2270375 & 110024541 & intron & $\mathrm{A}>\mathrm{G}$ & 1.89 \\
\hline$-()$. & 110028767 & intron & $\begin{array}{l}\text { TGGTGGGTGGT> } \\
\text { GGGGGGGGGGG }\end{array}$ & 0.94 \\
\hline rs35191208 & 110029008 & intron & $\mathrm{C}>\mathrm{T}$ & 3.08 \\
\hline rs 2270374 & 110029186 & intron & $\mathrm{G}>\mathrm{A}$ & 3.08 \\
\hline rs72648031 & 110029279 & intron & $\mathrm{C}>\mathrm{A}$ & 0.62 \\
\hline rs72648041 & 110032661 & intron & $\mathrm{T}>\mathrm{C}$ & 0.08 \\
\hline rs67606936 & 110011515 & 5'UTR & $\mathrm{A}>\mathrm{G}$ & 0.05 \\
\hline
\end{tabular}

Two SNPs of the ARPC1B gene in exons [rs4765 $(\mathrm{OR}=1.81)$ and $\mathrm{rs} 144187782(\mathrm{OR}=2.06)]$ are associated with severe acne $(P<0.05)$, and the rs1045012 SNP (OR=0.62) probably has a protective effect $(P<0.05)$ against the development of severe acne (Table 3 ). One of the 8 SNPs of the $A R P C 1 B$ gene in introns was described by us for the first time and was not previously described in any disease (Table 4). 
Table 3.

Characteristics of SNPs within exons of the ARPC1B gene in acne patients

\begin{tabular}{|c|c|c|c|c|c|}
\hline SNPid & $\begin{array}{c}\text { Position } \\
\text { Chr (7) }\end{array}$ & Substitution & $\begin{array}{c}\text { Exone } \\
\text { number }\end{array}$ & $\begin{array}{c}\text { Type and } \\
\text { position of } \\
\text { substitution }\end{array}$ & OR \\
\hline rs1045012 & 98984354 & nonsynonymous & 3 & c.G111C & 0.62 \\
\hline rs4765 & 98984399 & synonymous & 3 & c.C156T & 1.81 \\
\hline rs144187782 & 98992084 & nonsynonymous & 10 & c.C1091T & 2.06 \\
\hline
\end{tabular}

Table 4.

Characteristics of SNPs within introns and 5'UTR of the ARPC1B gene in acne patients

\begin{tabular}{|c|c|c|c|c|}
\hline SNPid & $\begin{array}{c}\text { Position } \\
\text { Chr (7) }\end{array}$ & $\begin{array}{c}\text { Intron/ } \\
\text { 3’UTR }\end{array}$ & $\begin{array}{c}\text { Type of } \\
\text { substitution }\end{array}$ & OR \\
\hline rs28377312 & 98984213 & intron & $\mathrm{G}>\mathrm{A}$ & 0.62 \\
\hline rs13236076 & 98985506 & intron & $\mathrm{G}>\mathrm{C}$ & 3.06 \\
\hline rs77167227 & 98985636 & intron & $\mathrm{C}>\mathrm{T}$ & 1.22 \\
\hline$-()$. & 98988999 & intron & $\mathrm{C}>\mathrm{G}$ & 2.06 \\
\hline rs10251282 & 98990236 & intron & $\mathrm{T}>\mathrm{C}$ & 0.62 \\
\hline rs529758052 & 98991916 & intron & $\mathrm{C}>\mathrm{T}$ & 1.22 \\
\hline rs41279845 & 98991939 & intron & $\mathrm{C}>\mathrm{T}$ & 0.40 \\
\hline rs10243678 & 98991944 & intron & $\mathrm{C}>\mathrm{T}$ & 1.15 \\
\hline rs704798 & 98992253 & 3'UTR & $\mathrm{G}>\mathrm{T}$ & 1.81 \\
\hline
\end{tabular}

Table 5 .

Characteristics of SNPS within exons of the CA2 gene in acne patients

\begin{tabular}{|c|c|c|c|c|c|}
\hline SNPid & $\begin{array}{c}\text { Position } \\
\text { Chr (8) }\end{array}$ & Substitution & $\begin{array}{c}\text { Exone } \\
\text { number }\end{array}$ & $\begin{array}{c}\text { Type and } \\
\text { position of } \\
\text { substitution }\end{array}$ & OR \\
\hline$-()$. & 86377646 & synonymous & 2 & c.C180G & 1.22 \\
\hline rs749549639 & 86385936 & nonsynonymous & 3 & c.C247T & 1.22 \\
\hline rs703 & 86389403 & synonymous & 5 & c.T259C & 1.68 \\
\hline
\end{tabular}

The OR results showed that 5 SNPs of the $A R P C 1 B$ gene in introns [rs13236076 (OR=3.06), rs77167227 (OR=1.22), -(.) $(\mathrm{OR}=2.06), \mathrm{rs} 529758052(\mathrm{OR}=1.22), \mathrm{rs} 10243678(\mathrm{OR}=1.15)]$ and SNP rs704798 in the 3'UTR $(\mathrm{OR}=1.81)$ are associated with the development of severe acne $(P<0.05)$, and 3 SNPs [rs28377312 (OR=0, 62), rs10251282 (OR=0.62), rs41279845 $(\mathrm{OR}=0.40)]$ seem to have a protective effect in the development of severe acne.

We diagnosed one of the 3 SNPs of the CA2 gene in exons for the first time both in patients with severe acne and in general among all diseases (Table 5). All 3 SNPs of the CA2 gene in exons [-(.) $(\mathrm{OR}=1.22)$, rs 749549639 $(\mathrm{OR}=1.22)$, rs 703 $(\mathrm{OR}=1.68)]$ are associated with severe acne $(P<0.05)$.

Six SNPs of the $C A 2$ gene in introns (Table 6) [rs 190187220 $(\mathrm{OR}=1.22), \mathrm{rs} 372186277(\mathrm{OR}=1.22), \mathrm{rs} 112597132(\mathrm{OR}=2.91)$, rs2307075 (OR=1.68), rs11780942 ( $\mathrm{OR}=1.15)$, and rs6605618 $(\mathrm{OR}=1.15)]$ are associated with severe acne.

At the same time, 2 SNPs of the CA2 gene [rs 117718682 $(\mathrm{OR}=0.13)$, rs552852909 $(\mathrm{OR}=0.13)$ ] are likely to have a protective value in the development of acne $(P<0.05)$.

Table 6.

Characteristics of SNPS within introns of the CA2 gene in acne patients

\begin{tabular}{|l|c|c|c|}
\hline \multicolumn{1}{|c|}{ SNPid } & $\begin{array}{c}\text { Position } \\
\text { Chr (7) }\end{array}$ & $\begin{array}{c}\text { Type of } \\
\text { substitution }\end{array}$ & OR \\
\hline rs190187220 & 86377731 & $\mathrm{G}>\mathrm{C}$ & 1.22 \\
\hline $\mathrm{rs} 117718682$ & 86377810 & $\mathrm{G}>\mathrm{T}$ & 0.13 \\
\hline $\mathrm{rs} 372186277$ & 86385870 & $\mathrm{G}>\mathrm{A}$ & 1.22 \\
\hline $\mathrm{rs} 112597132$ & 86386697 & $\mathrm{C}>\mathrm{T}$ & 2.91 \\
\hline $\mathrm{rs} 552852909$ & 86386699 & $\mathrm{G}>\mathrm{C}$ & 0.13 \\
\hline $\mathrm{rs} 2307075$ & 86388228 & $\mathrm{~A}>\mathrm{C}$ & 1.68 \\
\hline $\mathrm{rs} 11780942$ & 86389195 & $\mathrm{C}>\mathrm{T}$ & 1.15 \\
\hline $\mathrm{rs} 6605618$ & 86389586 & $\mathrm{~A}>\mathrm{C}$ & 1.15 \\
\hline
\end{tabular}

\section{Discussion}

Our study showed for the first time that there are differences in the frequencies of SNPs within genes involved in steroidogenesis in patients with severe acne. All 21 SNPs of the $M V K$ gene, 12 SNPs of the ARPC1B gene, and 11 SNPs of the $C A 2$ gene were first identified by us in patients with severe acne.

The results obtained on the difference in the frequencies of SNPs of genes encoding steroidogenesis indicate the genetic regulation of both the synthesis of steroid hormones and the response of a complex of specific tissue receptors localized both in the affected skin itself and in steroid-sensitive tissues. This provides a synergistic local and systemic response to steroid hormones and their metabolites with the development of a pathological skin process in acne.

The $M V K$ gene encodes the peroxisomal enzyme mevalonate kinase. Mevalonate is a key intermediate 
product, and mevalonate kinase is a key early enzyme in the synthesis of isoprenoids and sterols. In addition, expression of the $M V K$ gene protects keratinocytes from UFO-induced apoptosis. Mutations of the $M V K$ gene are probably responsible for the impaired synthesis of metabolites of steroid hormones, as well as an imbalance in the natural apoptosis of keratinocytes.

The $A R P C 1 B$ gene encodes one of 7 subunits of the human Arp2/3 protein complex. It has been shown that the ARP2/3 complex is co-localized with actin at the immune synapse in $\mathrm{CD} 8+$ human cytotoxic T-lymphocytes. In addition to its role in the cytoplasmic cytoskeleton, the Arp2/3 complex also promotes actin polymerization in the nucleus, thereby regulating gene transcription and repair of damaged DNA. It has also been shown that this gene is responsible for the tissue response to estrogens and estradiol. It is likely that the $A R P C 1 B$ SNPs result in an imbalance in the response of tissues, including skin, to estrogens, which contributes to the development of the pathological process in acne.

The $C A 2$ gene encodes a protein that is one of several isoenzymes of carbonic anhydrase, which are in the family of zinc metalloenzymes. The CA2 SNPs additionally affect the imbalance in the response of tissue receptors to steroid hormones in acne.

Our study showed that severe acne is associated with 12 polymorphic loci of the $M V K$ gene (4 SNPs in exons and 8 SNPs in introns), 7 SNPs of the $A R P C 1 B$ gene (2 SNPs in exons and 5 SNPs in introns), and 9 SNPs of the $C A 2$ gene (3 SNPs in exons and 6 SNPs in introns).

\section{Conclusion}

The revealed features of the SNPs within the $M V K, A R P C 1 B$, and $C A 2$ genes in patients with severe acne probably indicate a hereditary determination of steroidogenesis in acne. The imbalance in the work of the regulatory genes of androgens and estrogens apparently causes an imbalance in the androgen/estrogen ratio in the blood serum towards an increase in androgens against the background of a decrease in estrogens, while their values remain in the normal range.

Thus, our studies made it possible to identify and characterize the polymorphic loci of the $M V K, A R P C 1 B$, and $C A 2$ genes involved in the pathophysiological mechanism of the genetic determination of steroidogenesis in acne.

\section{Competing Interests}

The authors declare that they have no competing interests.

\section{References}

1. New MI. An update of congenital adrenal hyperplasia. Ann N Y Acad Sci. 2004 Dec;1038:14-43. doi: 10.1196/ annals.1315.009.

2. Chen WC, Zouboulis CC. Hormones and the pilosebaceous unit. Dermatoendocrinol. 2009 Mar;1(2):816. doi: 10.4161/derm.1.2.8354.

3. Orfanos CE, Adler YD, Zouboulis CC. The SAHA syndrome. Horm Res. 2000;54(5-6):251-8. doi: $10.1159 / 000053267$.

4. Imperato-McGinley J. 5alpha-reductase-2 deficiency and complete androgen insensitivity: lessons from nature. Adv Exp Med Biol. 2002;511:121-31; discussion 131-4. doi: 10.1007/978-1-4615-0621-8 8 .

5. Eklöf AC, Thurelius AM, Garle M, Rane A, Sjöqvist F. The anti-doping hot-line, a means to capture the abuse of doping agents in the Swedish society and a new service function in clinical pharmacology. Eur J Clin Pharmacol. 2003 Nov;59(8-9):571-7. doi: 10.1007/s00228-003-0633-z.

6. Cappel M, Mauger D, Thiboutot D. Correlation between serum levels of insulin-like growth factor 1, dehydroepiandrosterone sulfate, and dihydrotestosterone and acne lesion counts in adult women. Arch Dermatol. 2005 Mar;141(3):333-8. doi: 10.1001/archderm.141.3.333.

7. Inoue T, Miki Y, Kakuo S, Hachiya A, Kitahara T, Aiba S, Zouboulis CC, Sasano H. Expression of steroidogenic enzymes in human sebaceous glands. J Endocrinol. 2014 Sep;222(3):301-12. doi: 10.1530/JOE-14-0323.

8. Nagy I, Pivarcsi A, Kis K, Koreck A, Bodai L, McDowell A, Seltmann H, Patrick S, Zouboulis CC, Kemény L. Propionibacterium acnes and lipopolysaccharide induce the expression of antimicrobial peptides and proinflammatory cytokines/chemokines in human sebocytes. Microbes Infect. 2006 Jul;8(8):2195-205. doi: 10.1016/j.micinf.2006.04.001.

9. Szöllősi AG, Oláh A, Bíró T, Tóth BI. Recent advances in the endocrinology of the sebaceous gland. Dermatoendocrinol. 2018 Jan 23;9(1):e1361576. doi: 10.1080/19381980.2017.1361576.

10. Alestas T, Ganceviciene R, Fimmel S, Müller-Decker $\mathrm{K}$, Zouboulis CC. Enzymes involved in the biosynthesis of leukotriene B4 and prostaglandin E2 are active in sebaceous glands. J Mol Med (Berl). 2006 Jan;84(1):75-87. doi: 10.1007/ s00109-005-0715-8.

11. Barrault C, Garnier J, Pedretti N, Cordier-Dirikoc S, Ratineau E, Deguercy A, Bernard FX. Androgens induce sebaceous differentiation in sebocyte cells expressing a stable functional androgen receptor. J Steroid Biochem Mol Biol. 2015 Aug;152:34-44. doi: 10.1016/j.jsbmb.2015.04.005.

12. Dajnoki Z, Béke G, Kapitány A, Mócsai G, Gáspár K, Rühl R, Hendrik Z, Juhász I, Zouboulis CC, Bácsi A, Bíró T, Törőcsik D, Szegedi A. Sebaceous Gland-Rich Skin Is Characterized by TSLP Expression and Distinct Immune Surveillance Which Is Disturbed in Rosacea. J Invest Dermatol. 2017 May;137(5):1114-1125. doi: 10.1016/j. jid.2016.12.025.

13. Makrantonaki E, Zouboulis CC. Testosterone metabolism to 5alpha-dihydrotestosterone and synthesis of sebaceous lipids is regulated by the peroxisome proliferator-activated receptor ligand linoleic acid in human sebocytes. $\mathrm{Br} \mathrm{J}$ Dermatol. 2007 Mar;156(3):428-32. doi: 10.1111/j.13652133.2006.07671.x.

14. Deplewski D, Rosenfield RL. Role of hormones in pilosebaceous unit development. Endocr Rev. 2000 Aug;21(4):363-92. doi: 10.1210/edrv.21.4.0404.

15. Wei B, Qu L, Zhu H, Xiao T, Wei HC, Chen HD, He C. Higher 17 $\alpha$-hydroxyprogesterone levels aggravated 
the severity of male adolescent acne in Northeast China. Dermatology. 2014;229(4):359-62. doi: 10.1159/000365656.

16. Lam C, Zaenglein AL. Contraceptive use in acne. Clin Dermatol. 2014 Jul-Aug;32(4):502-15. doi: 10.1016/j. clindermatol.2014.05.002.

17. Makrantonaki E, Vogel K, Fimmel S, Oeff M, Seltmann $\mathrm{H}$, Zouboulis CC. Interplay of IGF-I and 17beta-estradiol at age-specific levels in human sebocytes and fibroblasts in vitro. Exp Gerontol. 2008 Oct;43(10):939-46. doi: 10.1016/j. exger.2008.07.005.

18. Szabó K, Kemény L. Studying the genetic predisposing factors in the pathogenesis of acne vulgaris. Hum Immunol. 2011 Sep;72(9):766-73. doi: 10.1016/j. humimm.2011.05.012.

19. Williams HC, Dellavalle RP, Garner S. Acne vulgaris.
Lancet. 2012 Jan 28;379(9813):361-72. doi: 10.1016/S01406736(11)60321-8. Epub 2011 Aug 29. Erratum in: Lancet. 2012 Jan 28;379(9813):314.

20. He L, Wu WJ, Yang JK, Cheng H, Zuo XB, Lai W, Gao TW, Ma CL, Luo N, Huang JQ, Lu FY, Liu YQ, Huang YJ, Lu QJ, Zhang HL, Wang L, Wang WZ, Wang MM, Xiao SX, Sun Q, Li CY, Bai YP, Li H, Zhou ZC, Zhou FS, Chen G, Liang B, Qi J, Yang XY, Yang T, Zheng X, Sun LD, Zhang XJ, Zhang YP. Two new susceptibility loci 1q24.2 and 11p11.2 confer risk to severe acne. Nat Commun. 2014;5:2870. doi: 10.1038/ ncomms 3870 .

21. Demirkan S, Sayın DB, Gündüz Ö. CAG polymorphism in the androgen receptor gene in women may be associated with nodulocystic acne. Postepy Dermatol Alergol. 2019 Apr;36(2):173-176. doi: 10.5114/ada.2019.84592. 